\title{
Pelatihan Penggunaan Aplikasi Pembelajaran Daring Untuk Mengoptimalkan Peran Guru Pada Pembelajaran Jarak Jauh (PJJ)
}

\author{
Eddy ${ }^{1}$, Ari Usman'2, Haida Dafitri ${ }^{3}$ \\ ${ }^{123}$ Fakultas Teknik \& Komputer, Universitas Harapan Medan \\ Email: eddy.stth.medan@gmail.com \\ Email: ariusman09@gmail.com \\ Email: aida.stth@gmail.com
}

\begin{abstract}
In order to prevent the increase in cases of exposure to COVID-19, the government has implemented several policies. In the field of education, the government stipulates that educational units or schools that are in the red zone are not allowed to carry out face-to-face learning activities. In this case students study at home and the teacher delivers course material online. To make this happen, of course the teacher must understand and master the online learning system. Currently there are several applications that can be used to support online learning, one of which is zoom meetings. Community service activities carried out at Harapan 3 Medan Private Elementary School aim to provide teachers with understanding and skills in the use of zoom meetings. From the training activities, it can be concluded that several things are: the teachers' understanding of IT is not evenly distributed, some teachers still find it difficult to understand the instructions given by the resource persons and the stability of the internet connection used by the participants varies so that it creates a few obstacles during the practice of zoom meetings.
\end{abstract}

Keywords: Online Learning, Applications, Zoom Meetings

\begin{abstract}
Abstrak
Dalam rangka mencegah bertambahnya kasus terpapar COVID-19 pemerintah telah melakukan beberapa kebijakan. Di bidang pendidikan pemerintah menetapkan bagi satuan pendidikan atau sekolah yang berada di zona merah tidak dibolehkan melaksanakan aktivitas pembelajaran secara tatap muka. Dalam hal ini murid belajar di rumah dan guru menyampaikan materi pelajaran secara daring. Untuk mewujudkan hal tersebut tentunya guru harus memahami dan menguasai sistem pembelajaran daring. Saat ini ada beberapa aplikasi yang dapat digunakan untuk mendukung pembelajaran daring, satu diantaranya adalah zoom meetings. Kegiatan pengabdian masyarakat yang dilaksanakan di SD Swasta Harapan 3 Medan bertujuan untuk memberi pemahaman dan keterampilan kepada para guru dalam penggunaan zoom meetings. Dari kegiatan pelatihan tersebut dapat disimpulkan beberapa hal yaitu: pemahaman IT para guru belum merata, beberapa guru masih sukar memahami intruksi yang diberikan narasumber dan kestabilan koneksi internet yang digunakan peserta bervariasi sehingga menimbulkan sedikit kendala pada saat dilakukannya praktik zoom meetings.
\end{abstract}

Kata Kunci: Pembelajaran Daring, Aplikasi, Zoom Meetings

\section{PENDAHULUAN}

Untuk mengantisipasi semakin meningkatnya wabah Virus Corona, pada tanggal 13 Maret 2020 pemerintah telah menetapkan Keppres No. 7 tahun 2020 tentang pembentukan Gugus Tugas

Percepatan Penanganan (GTPP) COVID-19. Pada tingkat pusat gugus tugas ini dipimpin oleh Kepala Badan Nasional Penanggulangan Bencana (BNPB). 
Selanjutnya pada pertengahan Maret 2020 Presiden Joko Widodo menghimbau kepada masyarakat agar melalukan social distancing untuk mencegah penyebaran Virus Corona atau COVID-19. Aktivitas yang selama ini dilaksanakan di luar rumah (outdoor), seperti: beribadah, bekerja dan belajar dapat dilakukan didalam rumah (work from home). Dengan penerapan work from home, diharapkan jumlah orang yang terinfeksi oleh Virus Corona atau CCOVID-19 tidak semakin meningkat.

Menindaklanjuti himbauan work from home tersebut pada tanggal 24 Maret 2020 Mendikbud mengeluarkan surat edaran tentang Pelaksanaan Kebijakan Pendidikan Dalam Masa Darurat COVID-19, yaitu Surat Edaran No.4 Tahun 2020. Dalam surat edaran tersebut dijelaskan bahwa proses pembelajaran bagi siswa dan mahasiswa dilaksanakan di rumah menggunakan sistem pembelajaran jarak jauh. Kegiatan pembelajaran tersebut dapat dilakukan secara daring (dalam jaringan) atau luring (luar jaringan). Pembelajaran jarak jauh tersebut dilaksanakan secara mandiri oleh siswa di bawah pengawasan orang tua atau wali siswa. Guru berperan sebagai fasilitator yang menyiapkan dan mendidtribusikan materi pelajaran kepada murid, kemudian melaksanakan evaluasi terhadap murid tersebut.

Tahun ajaran baru 2020/2021 telah ditetapkan oleh pemerintah dan akan dimulai pada pertengahan bulan Juli 2020. Surat Keputusan Bersama (SKB) 4 menteri yaitu: Menteri Pendidikan dan Kebudayaan, Menteri Agama, Menteri Kesehatan, dan Menteri Dalam Negeri mengatur penyelenggaraan pembelajaran pada tahun ajaran 2020/2021 dan tahun akademik 2020/2021, kemudian ditindaklanjuti oleh Surat Edaran Gubernur Sumatera Utara No : 205/GTCOVID-19/VII/2020. SKB tersebut dibuat dengan memperhatikan pembagian zona wilayah yang dikeluarkan oleh GTPP COVID-19, yakni: zona hijau, kuning, oranye dan merah. Penetapan zona tersebut akan menentukan seperti apa proses pembelajaran diselenggarakan di wilayah itu. Melalui SKB tersebut ditetapkan bahwa sekolah yang berada di zona merah, orange dan kuning tidak diperkenankan melakukan proses pembelajaran secara tatap muka. Dengan demikian bagi sekolah yang berada di zona tersebut melakukan proses pembelajaran jarak jauh atau daring. Menurut New England Complex Systems Institute (Maret 2020), untuk memantau dan respon yang efektif terhadap wabah digunakan 
identifikasi berdasarkan zona.

Dalam hal ini ada empat zona dalam identifikasi tersebut, yakni Zona Hijau, Kuning, Oranye, dan Merah:

a. Zona Hijau, merupakan wilayah atau daerah yang tak terdampak atau tidak tercatat kasus dan tidak ada penambahan kasus baru Covid-19 selama waktu tertentu. Pada zona hijau aktivitas masyarakat sudah bisa berjalan secara normal. Namun protokol kesehatan tetap harus diperhatikan seperti memakai masker, menjaga jarak dan lainlain.

b. Zona Kuning, diberikan pada daerah yang memiliki beberapa kasus penularan local COVID-19. Di zona ini bisa dilakukan Pembatasan Sosial Berskala Besar (PSBB) secara parsial.

c. Zona Oranye, diberikan pada daerah yang berdekatan dengan zona merah COVID-19, dimana penyebaran pada daerah ini relative tinggi. Selain melaksanakan upaya pencegahan, masyarakat di zona oranye diharuskan melakukan perlindungan diri, seperti: memakai masker, tunda/batalkan pertemuan yang tidak penting dan lain-lain.

d. Zona Merah, merupakan tanda yang diberikan untuk wilayah atau daerah yang berisiko tinggi penularan COVID-19. Pada daerah zona merah ini diberlakukan protokol kesehatan yang ketat, seperti: melakukan karantina bagi orang yang telah terinfeksi COVID-19, menutup tempat-tempat umum (sekolah, rumah ibadah, tempat bisnis), membatasi mobilitas penduduk dan lain-lain.

Sampai tanggal 27 Juli 2020 Pemerintah Provinsi Sumatera Utara melalui Gugus Tugas Percepatan Penanganan (GTPP) COVID-19 menyatakan kasus positif COVID-19 sebanyak 3.438 kasus. Sedangkan pasien yang sembuh berjumlah 931 pasien dan meninggal dunia sebanyak 181 orang. Menurut Gubernur Sumatera Utara selaku Ketua GTPP COVID-19, proses belajar tatap muka hanya boleh dilakukan pada daerah yang masuk kategori zona hijau. Di Sumatera Utara (update 27 Juli 2020), ada 3 kabupaten/kota berstatus resiko tinggi COVID-19 (zona merah) dari 33 kabupaten/kota yakni, Kota Medan, Kota Pematang Siantar dan Kabupaten Deli Serdang. Selebihnya, termasuk zona oranye, kuning dan hijau.

Kota Madya Medan merupakan salah satu kabupaten/kota yang berada di Provinsi Sumatera Utara. Kota Medan yang terdiri dari 21 kecamatan sampai dengan tanggal 27 Juli 2020 
terdapat 2101 kasus positif COVID-19, sebanyak 647 orang dinyatakan sembuh dan yang meninggal dunia sebanyak 109 orang. Dari data tersebut dapat disimpulkan bahwa kota Medan termasuk daerah yang berisiko tinggi penularan COVID-19 dan oleh GTPP COVID-19 ditetapkan sebagai zona merah (perkembangan penularan COVID-19 di Kota Medan dapat dilihat pada gambar 1). Mengacu pada SKB 4 menteri tentang penyelenggaraan pembelajaran pada tahun ajaran 2020/2021 pada saat pandemi COVID-19, maka satuan pendidikan atau sekolah yang berada di kota Medan tidak diperkenankan melakukan proses pembelajaran secara tatap muka. Mengikuti aturan pemerintah tersebut maka SD Swasta Harapan 3 Medan saat pandemi COVID-19 melakukan proses pembelajaran secara daring.

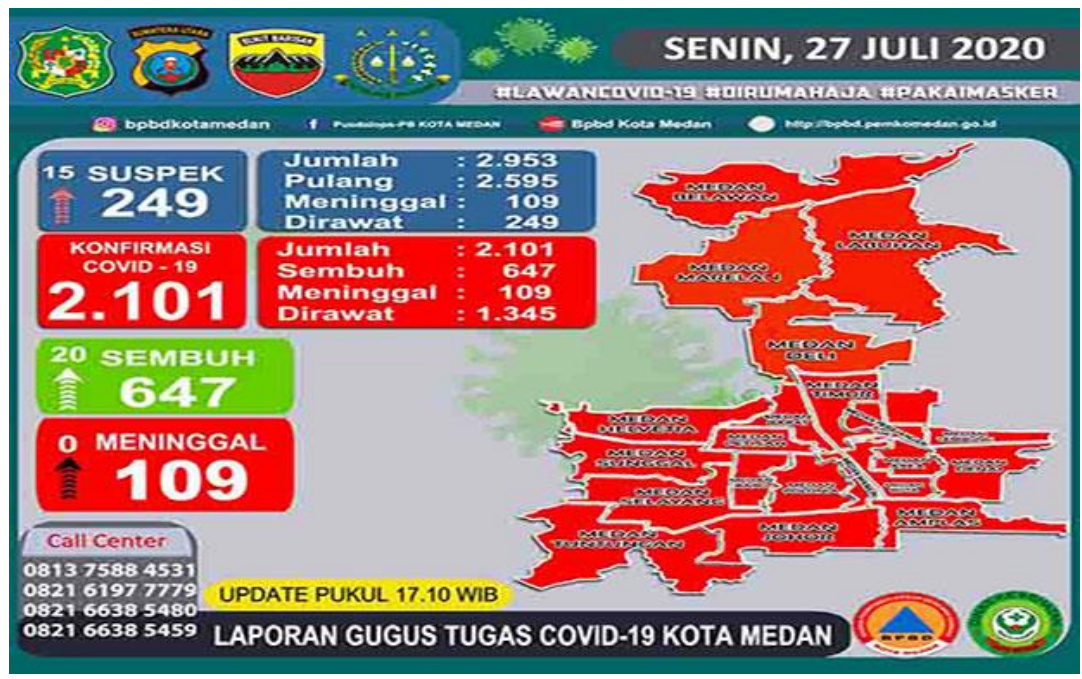

Gambar 1. Peta COVID-19 Kota Medan (Update 27 Juli 2020)

Dengan dilakukannya sistem pembelajaran daring pada satuan pendidikan yang berada di daerah zona merah, maka Kepala sekolah SD Swasta Harapan 3 Medan mengintruksikan kepada guruguru untuk melaksanakannya. Mengingat minimnya pengetahuan dan keterampilan guru disekolah tersebut dalam hal penggunaan aplikasi pembejaran daring, maka kepala sekolah mengundang kami sebagai tim pengabdian masyarakat Fakultas Teknik dan Komputer Universitas Harapan Medan untuk melakukan pelatihan penggunaan aplikasi pembelajaran daring.

Pembelajaran jarak jauh (daring) merupakan suatu inovasi dalam dunia pendidikan seiring dengan kemajuan di bidang Teknokogi Informasi. Hal ini sekaligus menjawab tantangan akan ketersediaan sumber belajar yang semakin variatif. Pada pembelajaran 
jarak jauh interaksi antara guru dengan siswa dapat berlangsung secara interaktif menggunakan platform aplikasi. Saat ini cukup banyak aplikasi yang dapat digunakan untuk pembelajaran daring, seperti: whatsapp group, classroom, moodle, edmodo, zoom meetings dan lain-lain. Pada kegiatan pelatihan ini, tim pengabdian masyarakat Fakultas Teknik dan Komputer, Universitas Harapan Medan memperkenalkan salah satu aplikasi pembelajaran daring yaitu zoom meetings. Dipilihnya aplikasi tersebut karena penggunaanya yang cukup massif, memiliki fitur-fitur yang sangat mendukung, dapat diakses dengan smartphone dan tidak dikenakan biaya.

\section{METODE PELAKSANAAN}

Pengabdian pada masyarakat di SD Swasta Harapan 3 Medan ini dilaksanakan dalam bentuk kegiatan pelatihan (workshop). Dalam pelaksanaanya kegiatan pelatihan ini dibagi atas 2 (dua) sesi, yaitu:

\section{a. Penyampaian Materi}

Dilakukan oleh tim pengabdian masyarakat Fakultas Teknik dan Komputer Universitas Harapan Medan, selaku narasumber. Penyampaian materi dilakukan melalui metode ceramah dan menggunakan Powerpoint. Metode ceramah adalah metode yang menekankan komunikasi melalui lisan. Ceramah merupakan metode pelatihan yang paling populer meskipun banyak metode lain yang digunakan saat ini dengan sentuhan teknologi seperti pembelajaran berbasis video dan komputer. Melalui metode ceramah ini materi dapat disampaikan dengan efisien kepada peserta pelatihan.

b. Unjuk Kerja dan Praktik

Unjuk kerja merupakan suatu kegiatan dimana peserta pelatihan diminta untuk mendemontrasikan pemahaman dan keterampilan terkait materi yang disampaikan. Hal ini dilakukan untuk menilai ketercapaian peserta pelatihan terhadap materi yang disampaikan. Untuk meningkatkan pemahaman teori yang disampaikan melalui kegiatan ceramah, maka selanjutnya dilakukan praktik (learning by doing). Beberapa peserta diberi kesempatan untuk melalukan praktik yang dipandu oleh narasumber. Praktik ini mencakup penggunaan fitur-fitur yang ada pada aplikasi pembelajaran daring yang akan digunakan. Kegiatan praktik ini bertujuan untuk mengembangkan keterampilan peserta pelatihan langkah demi langkah, secara bertahap menuju pencapaian kompetensi yang diharapkan. 


\section{HASIL DAN PEMBAHASAN}

Pelaksanaan pengabdian pada masyarakat dengan judul "Pelatihan Penggunaan Aplikasi Pembelajaran Daring Untuk Mengoptimalkan Peran Guru Pada Pembelajaran Jarak Jauh $(P J J) "$ telah dilaksanakan pada hari Kamis tanggal 9 Juli 2020, bertempat di aula SD Swasta Harapan-3 Medan. Pelatihan tersebut dilaksanakan dalam rangka persiapan untuk memulai kegiatan belajar mengajar pada Tahun Ajaran 2020/2021, yang telah ditetapkan pemerintah mulai dilaksanakan pada tanggal 13 Juli 2020. Sebagaimana disampaikan pada bagian pendahuluan bahwa sekolah yang berada di zona merah, oranye dan kuning tidak dibolehkan melaksanakan kegiatan pembelajaran tatap muka. Sehingga pembelajaran harus dilakukan secara daring (jarak jauh).

Untuk menyikapi pembelajaran daring, guru harus memahami dan menguasai aplikasi yang digunakan. Sehingga kegiatan pembelajaran daring tersebut dapat terlaksana dengan baik. Beberapa aplikasi yang dapat digunakan untuk pembelajaran daring, antara lain:

\section{a. Zoom Meetings}

Aplikasi zoom merupakan suatu layanan video conference yang berdasarkan komputasi awan (cloud computing). Guru dan murid dapat memanfaatkan aplikasi ini untuk melaksanakan pembelajaran jarak jauh (daring). Zoom memiliki beberapa fitur yang bisa dimanfaatkan untuk mendukung terjadinya interaksi antara guru dengan murid. Keberadaan fitur ini sangat mempermudah para penggunanya. Aplikasi zoom ini banyak digunakan di berbagai kalangan, seperti: sekolah, perguruan tinggi, perkantoran bahkan untuk kegiatan ceramah agama yang dilaksanakan secara online.

\section{b. Sevima EdLink}

Seorang guru seharusnya dapat memanfaatkan teknologi untuk memudahkannya dalam pelaksanaan proses belajar mengajar, untuk itu aplikasi Sevima Edlink dapat menjadi solusinya. Sevima Edlink merupakan aplikasi berbasis android sehingga dalam penggunaannya guru dan murid dapat mengandalkan smartphone. Melalui Sevima Edlink guru dapat: memberi materi pelajaran, memberi tugas dan dapat langsung memberi penilaian, berbagi informasi, mencantumkan file dan link untuk memudahkan murid memahami pelajaran dan lainlain. Dengan mengandalkan kolaborasi antara guru dan murid aplikasi ini sangat cocok 
digunakan pada pembelajaran daring, dan tentunya akan kelihatan lebih professional. Aplikasi ini dapat di unduh secara gratis di playstore.

\section{c. Moodle}

Moodle adalah sebuah platform bersifat open source yang dapat digunakan sebagai solusi kegiatan pembelajaran secara daring dengan biaya murah karena bisa digunakan secara gratis. Platformnya berbasis website, maksudnya seluruh kegiatan pembelajaran dilakukan dengan mengakses website menggunakan browser. Moodle merupakan suatu aplikasi belajar mengajar yang memanfaatkan teknologi informasi dan dikenal dengan istilah pembelajaran elektronik. Guru sebagai pengajar dapat mengupload bahan ajar, quis atau tugas dan lain-lain, kemudian murid dapat login ke Moodle dan selanjutnya memilih kelas yang sesuai untuknya. Aktivitas dan progress setiap murid dapat dipantau dengan mudah di dalam Moodle. Aplikasi Moodle terus berbenah seiring dengan perkembangan teknologi diantaranya dengan menjadikan aplikasi ini bersifat mobile friendly. Sehingga melalui aplikasi berbasisi iOS dan android dapat diakses.

\section{d. Google Classroom}

Google Classroom merupakan aplikasi yang menggabungkan Google Drive, Gmail, Google Dokumen dan Google Calender yang bertujuan untuk membantu guru membuat, mendistribusikan materi pelajaran dan tugas serta mengumpulkan tugas dengan cara tanpa memakai kertas. Layanan aplikasi google classromm ini bersifat gratis dan tersedia untuk perangkat android dan iOS sehingga dapat diakses menggunakan smartphone. Komunikasi guru dan murid bisa lebih intensif, dimana guru dapat mengajukan pertanyaan, memberi komentar dan menyampaikan pengumuman kepada murid.

\section{e. Edmodo}

Sebagaimana media pembelajaran daring lainnya, Edmodo merupakan sebuah platform online yang memungkinkan guru dan murid berkolaborasi pada kegiatan pembelajaran yang lebih kreatif. Aplikasi ini menjadi suatu hal yang menarik bagi guru, orang tua murid dan murid karena menyerupai media jejaring sosial facebook. Aplikasi ini memberi akses pada siswa untuk berinteraksi dengan guru dan rekan-rekannya dalam nuansa yang bersifat akademis. Pada dasarnya aplikasi ini mudah 
untuk dipelajari dan digunakan oleh guru dan murid karena tidak membutuhkan pengetahuan teknologi informasi yang rumit. Edmodo memiliki beberapa fitur yang fungsinya sama seperti course management system menyebabkan akses penggunaannya lebih cepat dan lebih mudah.

\section{f. Schoology}

Salah satu kemajuan teknologi yang kita rasakan di era revolusi industri 4.0 adalah kita dapat belajar dimanapun dan kapanpun asalkan terkoneksi dengan internet. Saat ini muncul beberapa media atau aplikasi yang bisa digunakan pada proses pembelajaran, salah satu diantaranya adalah Schoology. Aplikasi Schoology memadukan antara jejaring sosial dengan Learning Management System (LMS), sehingga penggunanya bisa belajar dan sekaligus berinteraksi sosial. Fokus utama Schoology adalah untuk memungkinkan terciptanya kolaborasi antar unsusr-unsur yang terlibat. Sama halnya dengan sebuah kelas Schoology juga terdiri dari guru dan murid. Guru dapat memberi materi pelajaran dan tugas serta dapat mengontrol hasil kerja siswa walapun dari jarak yang jauh. Pada Schoology orang tua murid juga diberi akses untuk memantau perkembangan dan kemajuan belajar anaknya di sekolah.

Pada kegiatan pelatihan ini aplikasi yang digunakan adalah zoom meetings. Sebagai peserta pelatihan adalah guru-guru SD Swasta Harapan-3 Medan. Lingkup pelatihan ini mulai dari pengenalan, cara mendaftar, menginstall, mengenal fitur-fitur pada zoom hingga penggunaan aplikasi zoom meetings.

Cara mendaftar dan menginstall zoom dengan menggunakan laptop.

a. Buka browser (mozilla atau chrome) dan ketik zoom meetings.

b. Buat akun zoom (klik Sign Up Free), input alamat email yang ingin didaftarkan pada kolom "email address". Kemudian klik tombol "Sign Up". Kita akan mendapatkan email verifikasi dari pihak zoom. (Bagi yang sudah memiliki akun Google, bisa menggunakan opsi "Sign in with Google" untuk menggunakan aplikasi zoom).

c. Masuk ke email yang kita daftarkan untuk memverifikasi akun zoom yang akan digunakan. Kemudian Klik "Activate Account", setelah diaktivasi maka kita akan langsung kembali ke halaman zoom.us.

d. Langkah berikutnya masukkan nama dan password yang ingin 
digunakan untuk akun zoom. Passwordnya minimal 8 karakter (menggunakan huruf dan angka serta terdiri dari huruf besar dan huruf kecil).

e. Klik "Continue".

f. Klik "Skip this step" g. Langkah selanjutnya klik"Start Meeting Now" untuk memulai pembelajaran daring.

(Bentuk tampilan aplikasi zoom meetings dapat dilihat pada gambar 2).

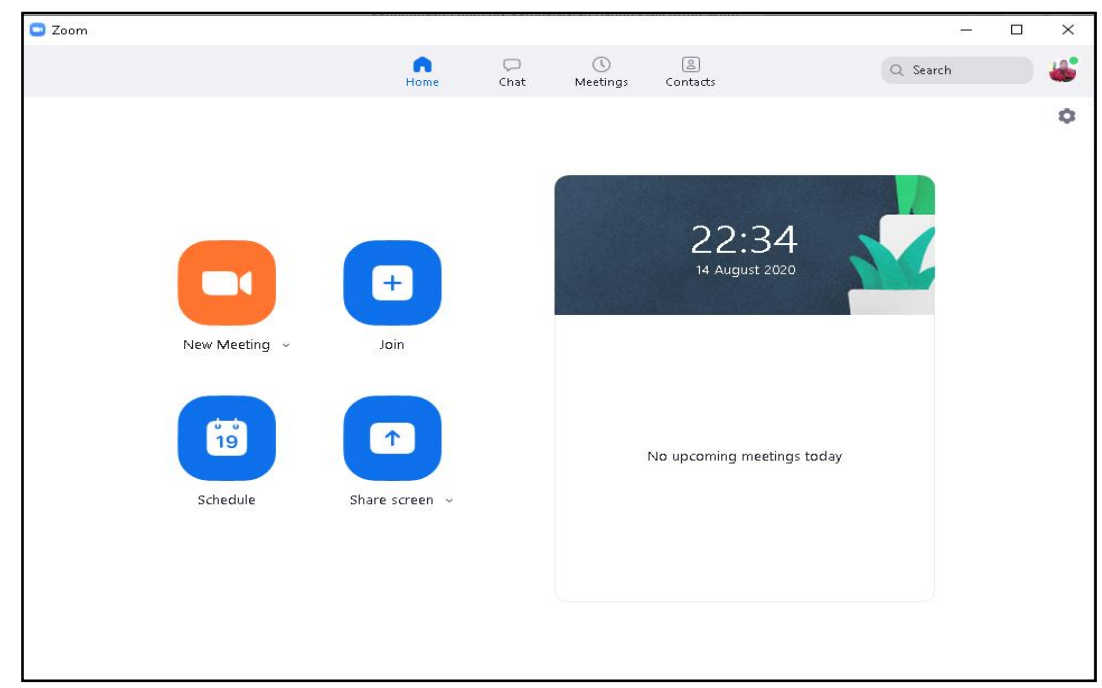

Gambar 2. Tampilan Aplikasi Zoom

Cara memulai pemebelajaran daring dengan zoom (guru sebagai host).

a. Buka aplikasi zoom yang sudah di install.

b. Klik "new meeting" untuk memulai pembelajaran daring.

c. Ketika sudah muncul ruang meeting, guru bisa mengundang murid dengan cara klik "invite". Mengundang murid dapat dilakukan secara instant melalui: email, zoom contact, dan copy URL.
Cara mengikuti pembelajaran daring dengan zoom (sebagai murid).

a. Buka aplikasi zoom yang sudah di install.

b. Kemudian klik link yang diberikan. Tetapi jika diberi "ID Meeting" klik menu "joint" kemudian input ID meeting tersebut beserta nama peserta pada kolom yang tersedia. 


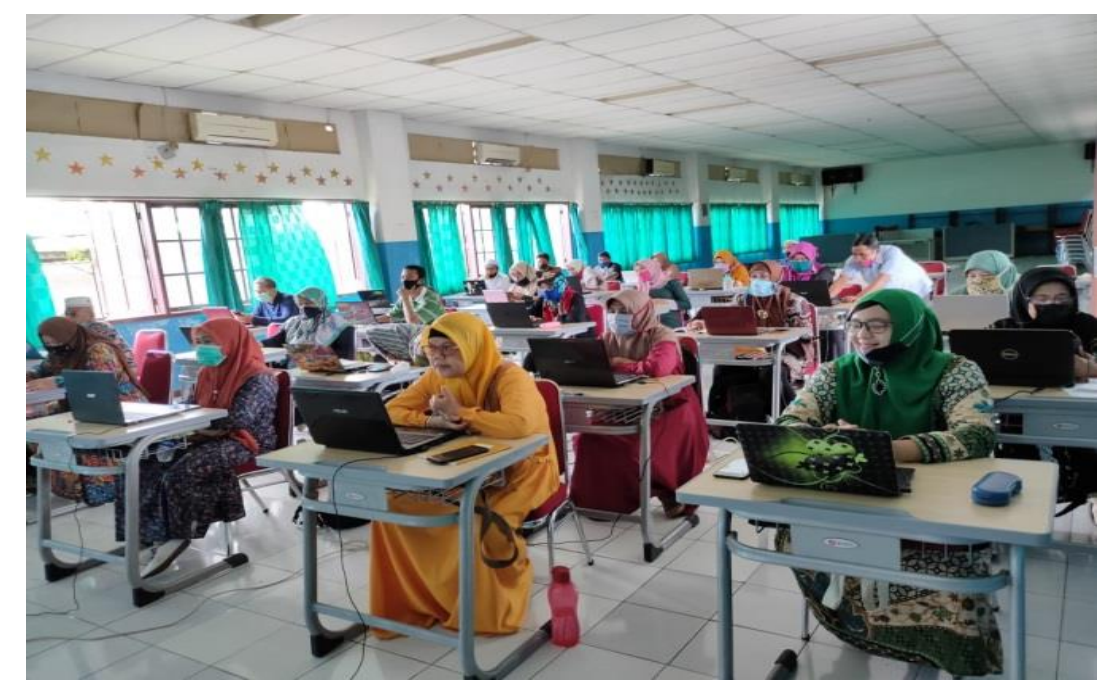

Gambar 3. Suasana Saat Berlangsungnya Kegiatan Pelatihan

Mengenal beberapa fitur zoom:

a. Host a meeting digunakan jika belajar daring (meeting) dilaksanakan saat itu juga. Ada tiga pilihan, with video off, with video on dan screen share only.

b. Join meeting digunakan bila ingin mengikuti belajar daring. Sebelumnya sudah diberi deskripsi meeting dan kode ID meeting.

c. Schedule a Meeting digunakan untuk menjadwalkan pemakaian zoom pada waktu tertentu dan mengirimkan undangan (link atau ID meeting) kepada murid untuk mengikuti belajar daring.

d. Share Screen digunakan untuk menampilkan powerpoint (PPT) yang akan dipresentasikan.

Informasi dari Kepala Sekolah, pembelajaran daring yang selama ini dilakukan hanya melalui
WhatsApp group. Oleh karena itu penggunaan aplikasi zoom ini adalah sesuatu yang baru dan belum pernah digunakan oleh guru SD Swasta Harapan-3 pada pembelajaran daring. Sebanyak 29 orang peserta mengikuti kegiatan pelatihan ini yang terdiri dari guru bidang studi dan guru kelas. Pada kesempatan pelatihan ini para guru melakukan praktik langsung penggunaan aplikasi untuk pembelajaran daring.

Setelah mengikuti pelatihan tentang penggunaan aplikasi zoom diharapkan para guru dapat:

a. Menggunakan aplikasi zoom meetings pada proses pembelajaran jarak jauh (daring).

b. Memiliki media pembelajaran alternatif untuk merangsang kreativitas dan inovasi para guru.

c. Berperan aktif menghambat penularan COVID-19 di masa 
pandemic ini dengan informasi di era revolusi industri menerapkan work from home.

d. Mengikuti dan beradaptasi dengan perkembangan teknologi

Berikut merupakan gambar suasana peserta melakukan praktik penggunaan aplikasi zoom.

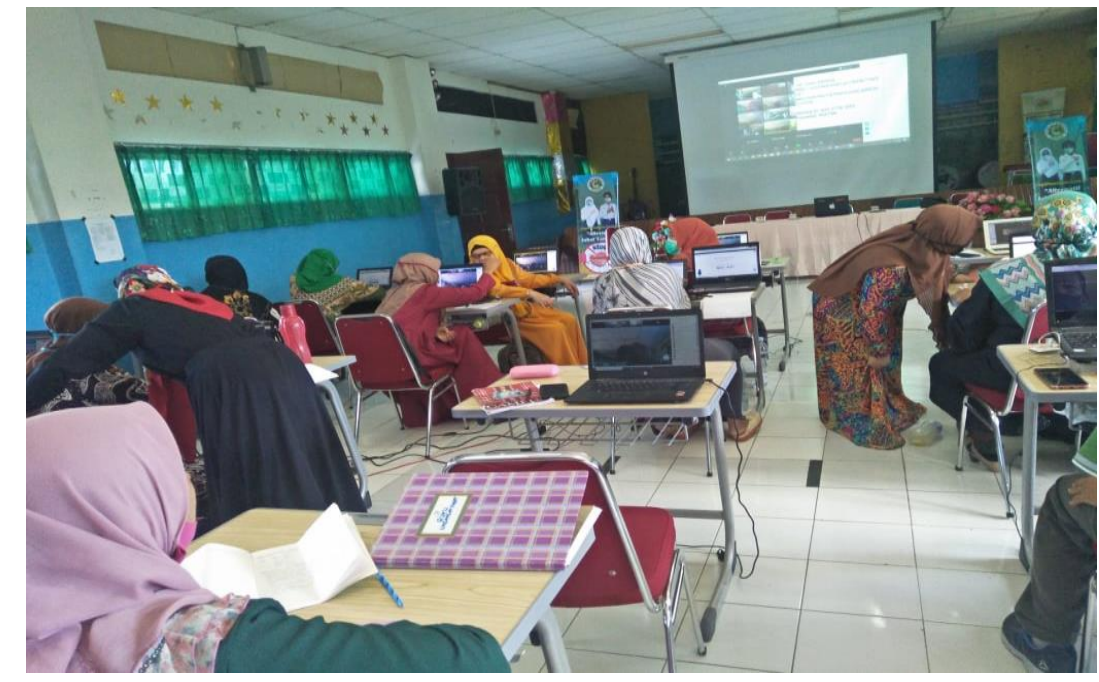

Gambar 4. Peserta Melakukan Praktik Penggunaan Aplikasi Zoom

\section{PENUTUP}

Di tengah pandemi COVID-19 yang melanda negara ini pemerintah telah melakukan berbagai upaya untuk mengatasi penyebaran COVID-19. Beberapa kebijakan telah dilakukan, satu diantaranya adalah penerapan work from home, dimana kegiatan belajar, beribadah dan bekerja dilakukan dari rumah. Dalam kaitannya dengan kegiatan pembelajaran di sekolah, pemerintah telah menetapkan bahwa sekolah yang berada di zona merah tidak dibolehkan melakukan kegiatan belajar tatap muka di sekolah. Dalam hal ini murid belajar di rumah dan guru menyampaikan materi pelajaran melalui pembelajaran jarak jauh (daring). Hal ini tentunya mengharuskan para guru untuk memahami dan menguasai aplikasi pembelajaran daring (misalnya zoom meetings). Untuk memberi pemahaman dan keterampilan mengenai aplikasi pembelajaran daring, maka dilakukan pelatihan terhadap guru SD Swasta Harapan 3 Medan. Dari kegiatan pelatihan tersebut beberapa hal dapat disimpulkan:

a. Belum meratanya pemahaman IT para guru.

b. Beberapa orang guru masih sukar memahami intruksi yang 
diberikan narasumber (mungkin karena faktor usia).

c. Kestabilan koneksi internet yang digunakan peserta pelatihan bervariasi, hal ini disebabkan karena menggunakan operator yang berbeda.

Adapun saran yang disampaikan dari kegiatan pelatihan ini yaitu:

a. Agar para guru selalu mengupdate kemampuan IT-nya.

b. Agar pihak sekolah dapat menyediakan koneksi internet yang lebih stabil.

\section{DAFTAR PUSTAKA}

Bilfaqih, Y., \& Qomarudin, M. N. (2015). Esensi Pengembangan Pembelajaran Daring. Sleman, Yogyakarta: Deepublish.

Conrad, R. M., \& Donaldson, J. A. (2004). Engaging the Online Learner: Activities and Resources for Creative Instruction. San Francisco: John Wiley \& Sons, Inc.

Hamilton, B. (2015). Integrating Technology in the Classroom: Tools to Meet the Needs of Every Student. Virginia: ISTE.

https://id.wikipedia.org/Google_Kelas. (2020, September 3).

https://id.wikipedia.org/Moodle. (2020, September 3).

https://id.wikipedia.org/pandemi_koron avirus_di_Indonesia. (2020, September 3).

https://idcloudhost.com/mengenalaplikasi-zoom-cara-install-dan- fitur-fitur-zoom-meetinglengkap. (2020, Agustus 14). https://kompaspedia.kompas.id/skbpembelajaran-tahun-ajaranbaru-di-masa-pandemi-covid-19. (2020, September 3).

https://medan.tribunnews.com/waspada -3-wilayah-di-sumut-berstatusrisiko-tinggi-kenaikan-kasuscovid-19. (2020, Agustus 14).

https://mediaindonesia.com/read/covid19-dan-pembelajaran-daring. (2020, Juli 28).

https://pahamify.com/blog/tutorialpembelajaran-menggunakanzoom. (2020, Juli 28).

https://sevima.com/Sevima-edlink. (2020, September 3).

https://www.nesabamedia.com/kelebiha n-dan-kekurangan-schoology. (2020, Agustus 14).

https://www.tagar.id/arti-zona-merahkuning-hijau-oranye-pandemicovid19. (2020, September 3).

Ko, S., \& Rossen, S. (2010). Teaching Online A Practical Guide, Third Edition. New York: Routledge.

Munir. (2009). Pembelajaran Jarak Jauh Berbasis Teknologi Informasi dan Komunikasi. Bandung: Alfabeta.

Sobron, B. R., \& Suswandari, M. (2020). Panduan Daring Learning. Sukoharjo, Jawa Tengah: Oase Pustaka.

Steve, R. (2020). Zoom Book: An Indepth Guide To Zoom App. USA: Gilob Publishing House. 